TẠP CHÍ KHOA HỌC ĐẠI HỌC ĐÀ LẠT Tập 11, Số 2, 2021 43-64

\title{
CẢM THỨC CỦA NGUYỄN DU VỀ TRUNG QUỐC THANH TRIỀU TRONG BĂC HÀNH TẠP LỤC
}

\author{
Lê Quang Trường ${ }^{\mathrm{a}^{*}}$
}

${ }^{a}$ Khoa Văn học, Trường Đại học Khoa học Xã hội và Nhân văn, Đại học Quốc gia TP. Hồ Chí Minh, TP. Hồ Chí Minh, Việt Nam

*Tác giả liên hệ: Email: lequangtruong@hcmussh.edu.vn

Lịch sử bài báo

Nhận ngày 22 tháng 01 năm 2021 | Chấp nhận đăng ngày 25 tháng 02 năm 2021

Xuất bản trực tuyến ngày 16 tháng 4 năm 2021

\section{Tóm tắt}

Nguyễn Du (1765-1820), tụe Tố Nhu, hiệu Thanh Hiên, biệt hiệu Hồng Son Liệp Hộ, nguời làng Tiên Điền, huyện Nghi Xuân, Hà Tĩnh. Họ Nguyễn ở Tiên Điền là danh gia vọng tộc, riêng gia đình Nguyễn Du có nhiều nguời làm quan dưới triều Lê-Trịnh. Tập ấm tù̀ cha mình, Nguyễn Du được phong Hoằng Tín đại phu, Vệ uý xuất thân, tuớc Thu Nhạc bá. Do đó trong thâm cảm của Nguyễn Du việc chịu ơn đức của Lê triều là điều xác tín. Nhung trong bổi cảnh xã hội phức tạp, sụ thay đổi chóng vánh tù chính quyền Lê-Trịnh sang Tây Sonn, rồi lại sang Nguyễn, khiến cho Nguyễn Du phải suy tu đến trầm tu, thậm chí khép mình sợ tiếp xúc vói nguời la khi miễn cuõng ra làm quan với triều Nguyễn. Năm Gia Long thư 12 (1813), Nguyê̂n Du được triều đình cử làm chánh sú sang Thanh tuế cống theo lệ. Trong chuyến đi này Nguyễn Du có tập tho "Bắc hành tạp luc". Gọi là tạp luc (ghi chép tạp nhạp), nhung ở đó người ta thấy nổi lên tu tuơơng và tình cảm của Nguyễ̂n Du qua nhũng trang ghi chép sinh động, điển hình về cảnh sắc, con người, văn hoá Trung Quốc duới triều Thanh vua Gia Khánh. Bài viết tiến hành khảo luận về những suy nghĩ, những cảm nhận của Nguyễn Du đối vói cảnh sắc con người đặc biệt là văn hoá Trung Quốc tù ghi chép của ông, cho thấy tính phản tur, đối thoại của một Việt nho trên đất Trung Hoa.

Từ khóa: Bắc hành tạp lục; Cảm thức; Nguyễn Du; Trung Quốc; Xâm thực văn hoá.

DOI: http://dx.doi.org/10.37569/DalatUniversity.11.2.839(2021)

Loại bài báo: Bài báo nghiên cứu gốc có bình duyệt

Bản quyền @ 2021 (Các) Tác giả.

Cấp phép: Bài báo này được cấp phép theo CC BY-NC 4.0 


\title{
NGUYEN DU'S PERCEPTION ABOUT CHINA UNDER THE QING DYNASTY THROUGH BAC HANH TAP LUC
}

\author{
Le Quang Truong ${ }^{\mathrm{a}^{*}}$ \\ ${ }^{a}$ The Faculty of Literature, University of Social Sciences and Humanities, Vietnam National University Ho \\ Chi Minh City, Ho Chi Minh City, Vietnam \\ *Corresponding author: Email: lequangtruong@hcmussh.edu.vn
}

Article history

Received: January $22^{\text {nd }}, 2021 \mid$ Accepted: February $25^{\text {th }}, 2021$

Available online: April 16 ${ }^{\text {th }}, 2021$

\begin{abstract}
Nguyen Du (1765-1820), with courtesy name To Nhu, poetic name Thanh Hien, and other pseudonym Hong Son Liep Ho, was born into the noble Nguyen clan of Tien Dien village in central Vietnam. Many of his family members served in high positions in the imperial mandarin system of the Le-Trinh dynasty. Inheriting honors from his father, Nguyen Du was bestowed the titles: Hoang Tin Great Man, Guard Commandant of Origin, and Thu Nhac Count. Therefore, deep within his conscience, Nguyen Du always felt indebted to the Le dynasty. However, the rapid replacement of the Le-Trinh by the Tay Son and then by the Nguyen dynasty during the chaotic years of the eighteen century seriously challenged his beliefs and emotions, pushing him into a reclusive lifestyle during his reluctant service to the Nguyen dynasty. In the $12^{\text {th }}$ year of Gia Long (1813), Nguyen Du was appointed the mission leader on a yearly tribute trip to China, during which he wrote a collection of poetry titled "Bac hanh tap luc" (Trivial Notes on the Northward Trip). His "trivial notes" revealed his complicated thinking and feelings about the Chinese landscape, people and culture under the rule of the Jiaqing emperor. This article analyzes Nguyen Du's rational and emotional perceptions of China, especially Chinese culture as implied in "Bac hanh tap luc", to better understand a case of direct interaction of a Vietnamese Confucian scholar with imperial China.
\end{abstract}

Keywords: Bac hanh tap luc; China; Cultural invasion; Nguyen Du; Perception.

DOI: http://dx.doi.org/10.37569/DalatUniversity.11.2.839(2021)

Article type: (peer-reviewed) Full-length research article

Copyright $\odot 2021$ The author(s).

Licensing: This article is licensed under a CC BY-NC 4.0 


\section{DÃ̃N NHậP}

Năm 1765, Nguyễn Du ra đời trong một gia đình quan lại cấp cao của triều LêTrịnh (cha là Nguyễn Nghiễm, bấy giờ là Thượng thư bộ Công, Tham tụng trong phủ Chúa từ 1764 đến 1774; anh Nguyễn Khản làm Bồi tụng). Năm Nguyễn Du được 11 tuổi, cha mất (1775), ba năm sau, mẹ mất (1778). Năm 1780, vụ án Canh Tý lập Trịnh Cán thay Trịnh Tông, Nguyễn Khản bị giam; cho đến khi Trịnh Tông lên ngôi chúa, Nguyễn Khản được phục chức Thượng thư bộ Lại, tước Toản quận công; Nguyễn Đề (Nễ) làm Đô đốc phủ sứ, tước Điền Nhạc hầu. Năm 1783, Nguyễn Du thi đậu tam trường (tú tài) trường Sơn Nam (cùng đó, anh là Nguyễn Đề, em là Nguyễn Nhưng, cháu là Nguyễn Thiện đều đỗ tứ trường (cử nhân) trường Phụng Thiên). Nhưng chỉ năm sau, vụ kiêu binh nổi dậy đốt phá cơ dinh nhà Nguyễn Khản khiến anh em li tán. Năm 1786, Nguyễn Du giữ chức Chánh thủ hiệu Thái Nguyên, rồi lấy vợ là em gái của Đoàn Nguyễn Tuấn, con của Đoàn Nguyễn Thục. Cùng năm Tây Sơn chiếm lấy Huế, ra bắc lấy trấn Sơn Nam, vào thành Thăng Long. Vua Lê Hiển Tông mất, Lê Chiêu Thống lên ngôi. Các anh Nguyễn Khản, Nguyễn Điều mất. Nguyễn Hữu Chỉnh chuyên quyền, Tây Sơn ra bắc lần thứ hai, vua Chiêu Thống bỏ chạy. Anh em nhà Nguyễn Du lại li tán. Năm 1789, Tây Sơn đại thắng quân Thanh, Chiêu Thống trốn sang Trung Quốc, nhà Lê mất ngôi kéo theo sự nghiệp phò Lê của các cựu thần thất bại. Nhà Tây Sơn hiểu dụ các quan triều Lê ra giúp sức cho triều Tây Sơn, nhiều người ra làm quan với tân triều, trong đó có Nguyễn Đề và Đoàn Nguyễn Tuấn. Năm 1802, Nguyễn Ánh diệt triều Tây Sơn, lập triều Nguyễn, Nguyễn Du ra làm quan. Khởi từ chức tri huyện Phù Dung, Nguyễn Du được cất làm tiếp sứ (1803), thăng làm Đông các học sĩ, tước Du Đức hầu (1805); rồi Cần chánh điện học sĩ, được cử làm chánh sứ sang Thanh tuế cống năm 1813; Hữu tham tri bộ Lễ (1815), chuẩn bị đi sứ năm 1820 để báo tang vua Minh Mạng thì mất vì bệnh dịch, thọ 56 tuổi. (Nguyễn \& Trương, 2001).

Nói tóm tắt về cuộc đời Nguyễn Du trong một bối cảnh xã hội biến động như thế để từ đó lý giải thêm về nỗi lòng sâu kín của Nguyễ̂n Du. Chứng kiển cảnh triều đại đổi thay chóng vánh, các giá trị văn hoá truyền thống bị nghịch đảo trong xã hội quân chủ đã đến hồi cuối, Nguyễn Du cảm thức về đời sống sâu sắc hơn, chiêm nghiệm về thói đời thấu đáo hơn qua những trang thơ. Từ một người đầy "hùng tâm" chí để bốn phương, Nguyễn Du dần dần trở thành một người lúc nào cũng chỉ muốn trở về núi Hồng sống "nhàn dật". Dầu khi con đường làm quan của ông đang hanh thông rộng mở, ông vẫn dũng cảm giũ áo từ quan. Nhiều nhà nghiên cứu lý giải tâm trạng đầy phức tạp của Nguyễn Du, thông qua bộ phận sáng tác thơ chữ Hán của ông, nguyên khởi từ nhận thức về hiện thực xã hội đương thời, hay từ cảm nhận về sự vô thường trong vũ trụ nhân sinh, hay từ những căn nguyên văn hoá... bằng nhiều cách khác nhau (Khoa Văn học và Ngôn ngữ, 2015). Song mọi nghiên cứu dù đạt được những kết quả nhất định, vẫn có phần chưa lý giải hết và hiểu hết về một người "rụt rè" khi giao tiếp, một tấm lòng khó giải bày "sâu như sông Quế" Nguyễn Du. Vì thế, ở một hướng tiếp cận mang tính truyền thống, đọc sâu văn bản (close reading), người viết muốn khởi từ đó để nhận thức thêm cảm thức của Nguyễn Du thể hiện trong tập thơ đi sứ ngõ hầu lý giải thêm về những ẩn khuất Nguyễn Du.

Năm Gia Long thứ 12 (1813), Nguyễn Du được triều đình cử làm chánh sứ sang Thanh tuế cống theo lệ. Trong chuyến đi này Nguyễn Du có tập thơ Bắc hành tạp lục. 
Gọi là tạp lục (ghi chép tạp nhạp), nhưng ở đó ta thấy nổi lên tư tưởng và tình cảm của Nguyễn Du qua những trang ghi chép sinh động, điển hình về cảnh sắc, con người, văn hoá Trung Hoa dưới triều Thanh (thời vua Gia Khánh). Khảo sát và đọc lại tập thơ Bắc hành tạp luc (A.1494), người viết nhận thấy, ngòi bút của Nguyễn Du trong chuyến du hành lên phương bắc không những phản ánh các góc cạnh của đời sống Trung Hoa, nó còn cho thấy những cảm nhận mang tính phản tư, những suy nghĩ có tính cật vấn và đối thoại về xã hội và văn hoá lân quốc. Cái nhìn của Nguyễn Du về xã hội và con người Trung Hoa, như cách nói của Huỳnh Như Phương, "điềm tĩnh và gan ruột", và có phần "thất vọng” trước một nước có “tầm vóc về địa lý và văn hoá” (Huỳnh \& Đoàn, 2015, tr. 6-7)

\title{
2. CẢM THỨC VỀ VĂN HOÁ SUY TÀN TRONG CÁI NHÌN SO SÁNH VÀ SUY TƯ KỲ DI!
}

Cảm nhận đầu tiên và dường như thường trực trong lòng Nguyễn Du là sự đổi thay của cuộc sống, đất nước và vũ trụ. Trên đường đi sứ, ngang qua thành Thăng Long, Nguyễn Du cảm khái trước cảnh đổi thay của đất nước:

\author{
古時明月照新城, 猶是昇龍舊帝京。 \\ 忂巷四開迷舊跡, 管弦一變雜新聲。 \\ 千年富貴供爭奪, 早歲親朋半死生。 \\ 世事浮沉休嘆息, 自家頭白亦星星。 \\ 《昇龍・其二》(Nguyễn, 1813, tr. 4b)
}

Phiên âm:

Cổ thì minh nguyệt chiếu tân thành, Do thị Thăng Long cưu đế kinh. Cù hạng tứ khai mê cựu tích, Quản huyền nhất biến tạp tân thanh.

Thiên niên phú quý cung tranh đoạt, Tảo tuế thân bằng bán tủe sinh.

Thế sụ phù trầm hưu thán tức, Tự gia đầu bạch diệc tinh tinh.

\section{(Thăng Long, kỳ nhị)}

Dịch: Trăng sáng ngày xưa soi toà thành mới, thành Thăng Long vẫn là kinh đô của bậc đế vương xưa. Ngõ đường mở ra bốn phía làm mờ dấu tích cũ, tiếng sáo đàn đã thay đổi chen lẫn điệu mới lạ. Giàu sang ngàn năm chỉ khiến cho người ta tranh đoạt, bè bạn người thân thuở trước một nửa đã mât. Chuyện đời thăng trầm xin đừng than thở, thân mình, đầu cũng đã lốm đốm bạc rồi ${ }^{1}$

\footnotetext{
${ }^{1}$ Nguyên văn chữ Hán đều được trích từ Bắc hành tạp lục, ký hiệu A.1494, Thư viện Viện Nghiên cứu Hán Nôm Hà Nội lưu trữ. Các bản dịch nghĩa trong bài đều của người viết.
} 
Trong cảm nhận của Nguyễn Du, Thăng Long vẫn là kinh đô cũ, nhưng là thành trì mới của tân triều, những con đường mở rộng làm mờ dấu tích xưa, tiếng nhạc pha điệu mới, người đã mất, ta đầu bạc... Dù đó là những cảm nhận về thế sự thăng trầm, về một cuộc đời thay đổi vô thường, nhưng trong sự đổi thay đó, Nguyễn Du vẫn cảm nhận được vẻ thanh bình của đất nước qua các triều đại bằng ảnh tượng tiếng nhạc văn hoá. Nghĩa là không có một sự gãy đứt văn hoá. Đó là điểm mà Nguyễn Du thầm tự hào văn hoá nước Việt khi nhìn về Trung Hoa. Không những tự hào văn hoá thời đại Lý-Trần, Nguyễn Du còn tự hào về văn hoá hào hùng thời Hậu Lê:

$$
\begin{aligned}
& \text { 李陳舊事杳難尋, 三百年來直到今。 } \\
& \text { 兩國平分孤壘面, 一關雄鎮萬山心。 } \\
& \text { 地偏每為傳聞誤, 天近䌆知降澤深。 } \\
& \text { 帝關回頭雲碧表, 鈞韶耳畔有餘音。 }
\end{aligned}
$$$$
\text { 《鎮南關》(Nguyễn, 1813, tr. 5b-6a) }
$$

Phiên âm:

$$
\begin{aligned}
& \text { Lý Trần cựu sự yểu nan tầm, Tam bách niên lai trục đáo kim. } \\
& \text { Luõ̃ng quốc bình phân cô luỹ diện, Nhất quan hùng trấn vạn son tâm. } \\
& \text { Địa thiên mỗi vị truyền văn ngộ, Thiên cận tài tri giáng trạch thâm. } \\
& \text { Đế khuyết hồi đầu vân bích biểu, Quân thiều nhĩ bạn hữu du âm. } \\
& \text { (Trấn Nam Quan) }
\end{aligned}
$$

Dịch: Chuyện xưa triều Lý, triều Trần mịt mờ khó tìm lại, cơ nghiệp [của nhà Lê] tính đến nay đã ba trăm năm. Hai nước ngang bằng chia nhau bởi mặt luỹ, một cửa ải hùng tráng trấn giữ giữa muôn ngàn núi non. Nơi hẻo lánh thường bị sai tin tức, ở gần trời mới thấy ơn mưa móc sâu dày. Ngoảnh đầu về cửa khuyết trong màu xanh biếc của mây xa, bên tai còn nghe dư âm khúc nhạc thiều.

Khúc "nhạc thiều" từ các triều đại trước vẫn còn vang vọng trong tâm cảm Nguyễn $\mathrm{Du}$, dư âm của nó còn rộn ràng trong cung điện triều Nguyễn và vang vọng bên tai vị quan đại thần xuất sứ. Dù tiếng nhạc có chút thay đổi, nhưng trong tâm cảm Nguyễn Du, biểu tượng văn hoá vẫn hiện diện trên non sông Đại Việt. Lần đầu tiên Nguyê̂n Du xuất sứ Trung Hoa, nhưng khác với các sứ thần trước và sau đó đi sứ là một việc đáng tự hào trong đời làm quan, Nguyễn Du ngược lại, chỉ cảm thấy lạnh xương khi nghĩ tới ơn vua:

\section{玉書捧下五雲端，萬里單車渡漢關。……}

\footnotetext{
${ }^{2}$ Nguyên văn chép “碧雲 bích vân”, chúng tôi đảo lại thành “雲碧 vân bích” để hợp niêm luật.
} 


\section{君恩似海毫無報, 春雨如膏骨自寒。}

王道蕩平休問訊, 明江北上是長安。

《南關道中》(Nguyễn, 1813, tr. 6a)

Phiên âm:

Ngọc thư phủng há ngũ vân đoan, Vạn lý đan xa độ Hán quan...

Quân ân tự hải hào vô báo, Xuân vũ nhu cao cốt tự hàn.

Vuoong đạo đãng bình huu vấn tấn, Minh Giang bắc thướng thị Truờng An.

\section{(Nam Quan đạo trung)}

Dịch: Chiếu thư ban ra từ cõi trời mây ngũ sắc, một chiếc xe cô độc vượt qua cửa ải sang Hán... Ơn vua sâu rộng như biển mà chưa báo đáp được, mưa xuân như gội, thấy xương mình buốt lạnh. Đạo vua (đường sứ Hoa) bằng phẳng hẳn chẳng cần hỏi chi, từ sông Ninh Minh cứ thẳng lên bắc thì đến Trường An?

Trong lo lắng ưu tư về con đường đi sứ người ta thường nghĩ đến ơn tri ngộ và sự đáp đền. Nguyễn Du không ngoại lệ, vẫn tự an ủi mình bằng hai câu thơ đầy tâm trạng về con đường sứ Hoa: Con đường sứ chắc phẳng bằng như vương đạo (con đường, đường lối cai trị) ở Trung Quốc, chẳng cần phải thăm hỏi làm chi, cứ đi thẳng ắt đến được kinh đô. Nhưng cảm nhận (khá lạc quan) này sẽ dần thay đổi trên đường đi sứ của Nguyễn Du. Song, đó cũng là một trong những cách cảm cách nhìn của Nguyễn Du về một đất nước "tầm cỡ" khi ông chưa thực sự đặt chân lên miền đất khách. Một sự lầm tưởng về "đại quốc" có lẽ đã diễn ra trong Nguyễn Du khởi từ khi vua quan Lề Chiêu Thống bôn đào cầu viện. Nguyễn Du đã không kịp theo trong chuyến đi đó, tưởng bất hạnh lại trở thành một may mắn trong đời ông. Nỗi đau mất nước từ những ảo tưởng về sự trợ giúp bên ngoài dẫn đến việc vua Chiêu Thống cùng các bầy tôi phải gửi xác thân của họ trên đất khách (phải đến những năm 1805 mới được triều Nguyễn xin đưa hài cốt về cố quốc,) hẳn đã khiến cho Nguyễn Du mơ hồ nhận ra "diện mục" của nhà cầm quyền Trung Hoa thời ấy - Thanh triều. Vì thế con đường đi sứ của ông là con đường của những nỗi nhớ:

$$
\begin{array}{r}
\text { 舟人爭指家鄉近，惱殺殊方老使臣。 } \\
\text { 《過天平》(Nguyễn, 1813, tr. 4a) }
\end{array}
$$

Phiên âm:

Chu nhân tranh chỉ gia huoong cận, Não sát thù phuoong lão sứ thần.

(Quá Thiên Bình)

Dịch: Người trong thuyền tranh nhau chỉ quê hương gần đây thôi, khiến lòng lão bầy tôi phương xa buồn muốn chết. 
別後關山思弟妹，望中岩岫見兒孫。

日斜莫向華山過，怕有聲聲腸斷猿。

《明江舟發》(Nguyễn, 1813, tr. 6b)

Phiên âm:

... Biệt hậu quan son tu đệ muội, Vọng trung nham tụ kiến nhi tôn.

Nhật tà mạc hướng Hoa Sơn quá, Pha hưu thanh thanh truờng đoạn viên.

(Minh Giang chu phát)

Dịch: Sau khi chia tay nơi cửa ải lòng nhớ đến em trai am gái, trông vời núi non cứ tưởng như thấy cháu con. Chiều xế chớ nên ngang qua núi Hoa Sơn, e rằng từng tiếng vượn kêu khiến lòng đứt đoạn.

Là con đường gợi nhắc một câu chuyện buồn của lịch sử với nỗi cô đơn ghê gớm: “經旬去國心如死, 一路逢人面盡生” (Rời nước muơi ngày, lòng tưa chết/ Gặp nguời đất khách, mặt không quen); để cảm nhận sâu hơn 10 năm gió bụi loạn lạc của đời mình: “十年已失還鄉路, 那得家鄉入夢頻” (Mười năm mất lối về quê cũ / Đến nỗi quê huơng mộng khó vào). Suốt chặng đường sứ, hiếm hoi lắm ta mới gặp cái kiểu nói khách sáo của Nguyễn Du: “為憐上國風光好, 關鎖鄉情未放歸” 《舟行即事》 (Mùng vì thương quốc cảnh quang đẹp/ Khoá chặt tình quê chẳng được về - "Chu hành tức sự"); còn lại, Nguyễn Du cảm nhận về cảnh vật trên đất khách đa số dưới góc nhìn kỳ dị. Kỳ dị bởi lần đầu đi sứ nhìn thấy phong cảnh thiên nhiên hùng vĩ, nhưng cũng không thể không lý giải nó ở góc độ tâm lý, đầu óc tưởng tượng phong phú của Nguyễn Du. Dưới góc nhìn đó, cảnh vật con đường sứ xa thẳm diệu vợi, khó khăn đầy rẫy những bùn lầy và lũ yêu tinh:

$$
\begin{aligned}
& \text { 山麓積泥深沒馬, 谿泉伏怪老成精。 } \\
& \text { 客情至此已無限, 又是燕山萬里行。 } \\
& \text { 《幕府即事》(Nguyễn, 1813, tr. 6a) }
\end{aligned}
$$

Phiên âm:

Son lộc tích nê thâm một mã, Khê tuyền phục quái lão thành tinh.

Khách tình chí thử dĩ vô hạn, Hựu thị Yên sơn vạn lý hành.

(Mạc phủ tức sụ)

Dịch: Chân núi chứa bùn lầy sâu đến ngập cả ngựa, suối khe có yêu quái ẩn núp từ lâu đã thành tinh. Nỗi lòng khách đến đây thật đã buồn vô hạn, lại còn cả vạn dặm đường nữa mới đến non Yên. 
Cảnh vật nơi đất khách được Nguyễn Du miêu tả độc đáo, trước và sau ông chưa từng có. Dưới một góc nhìn kỳ dị trong một suy tư dị kỳ, Nguyễn Du đã thấy ở đó những hổ báo rắn rồng như chực nuốt lấy người, nước vọt như tên bắn như chực ghim lấy người, dìm lấy người:

粵西山中多澗泉, 千年合注成一川, 自高而下如潑天。灘上何所聞: 應龍 激怒雷田田。灘下何所見: 㛎機劇發矢離絃。一瀉萬里無停煙, 高山夾岸 如牆垣, 中有怪石森森然。有如龍蛇虎豹牛馬羅其前, 大者如屋小如拳。 高者如立低如眠, 直者如走曲如旋。千形萬狀難盡言, 蛟螭出沒成重淵。 湧濤噴沫日夜爭豕喧, 夏潦初涨沸如煎。一行三日心懸懸, 心懸懸多所畏。 危乎殆哉汨沒無底, 共道中華路坦平。中華道中夫如是, 窩盤屈曲似人心。

\section{《寧明江舟行》(Nguyễn, 1813, tr. 7a)}

Phiên âm: Việt Tây sơn trung đa giản tuyền, Thiên niên hợp chú thành nhất xuyên, Tư cao nhi há nhu bát thiên. Than thương hà sở văn: Ung long khích nộ lôi điền điền. Than hạ hà sở kiến: Nỗ co kịch phát thỉ ly huyền. Nhất tả vạn lý vô đình yên, Cao sơn giáp ngạn nhu tuờng viên. Trung hũu quái thạch sâm sâm nhiên, Hũu nhu long xà hổ báo ngưu mã la kỳ tiền. Đại giả nhu ốc tiểu nhu quyền, Cao giả nhu lập đê nhu miên. Trục giả nhu tẩu khúc như tuyền, Thiên hình vạn trạng nan tận ngôn. Giao ly xuất một thành trùng uyên, Dũng đào phún mạt nhật dạ tranh hôi huyên. Hạ lạo sơ truớng phí nhur tiên, Nhất hành tam nhật tâm huyền huyền. Tâm huyền huyền đa sở uý, Nguy hồ đãi tai mịch một vô để. Cộng đạo Trung Hoa lộ thản bình, Trung Hoa đạo trung phù nhu thị: Oa bàn khuất khúc tụ nhân tâm (Ninh Minh giang chu hành)

Dịch: Trong núi vùng Quảng Tây nhiều khe suối, ngàn năm hợp thành một dòng sông, từ trên cao đổ xuống như vọt ra khỏi trời. Trên ghềnh ta nghe gì: như rồng nổi giận rống tiếng ầm ầm. Dưới ghềnh ta thấy gì: như nỏ bật mạnh tên rời dây, một dòng trôi muôn dặm không ngừng khói toả. Hai bờ núi cao như bức tường, trong có đá quái dị chen chúc nhau. Có hòn như rồng rắn hổ báo trâu ngựa bày phía trước, hòn lớn to như cái nhà, nhỏ thì như nắm tay. Hòn cao thì như đứng, hòn thấp thì ngủ gật gù, hòn thẳng thì như chạy, hòn cong thì như xoay. Muôn hình vạn trạng không nói hết được, thuồng luồng, giao long ra vào thành vực thẳm. Sóng tung bọt ngày đêm tranh nhau gào rầm rầm, lũ đầu mùa hè nước trào sôi sục. Đi ba ngày liền mà lòng lo thấp thỏm, lòng thấp thỏm bởi có nhiều điều sợ: Nguy hiểm thay, chìm sâu không thấy đáy, vậy mà ai cũng bảo đường Trung Hoa bằng phẳng. Thì ra con đường Trung Hoa là thế này: quanh co khúc khuỷu giống như lòng người.

Thiên nhiên Trung Hoa dưới ngòi bút Nguyễn Du trở thành những thú dữ kỳ độc, vừa đủ phô diễn cái khí thế hùng vĩ của nó, vừa âm thầm bày tỏ cái đáng sợ trên đường sứ Hoa. Nếu chỉ đọc những câu thơ tả cảnh núi non trên kia, người ta có thể chỉ nghĩ đến óc tưởng tượng phong phú của Nguyễn Du, có thể khen tài tả cảnh tả vật của ông, và biết đâu lại bỏ qua một sự thâm trầm ý tứ. Trong cảnh vật kỳ dị đó, người ta thấy Nguyễn Du luận về con đường Trung Hoa. Con đường ở Trung Hoa, hay "Trung Hoa đạo" ở đó khúc khuỷu quanh co, sâu thẳm vô đáy, nguy hiểm như lòng người. Con đường đó, cũng giống 
với điều mà nho gia cho rằng "nhân tâm duy nguy, đạo tâm duy vi" (lòng người nguy hiểm, tâm đạo sâu xa), thật khác với cảm nhận ban đầu của Nguyễn Du như có lần ông từng nói trong bài Nam Quan đạo trung.

Quan niệm phương Đông cho rằng: đất thiêng sinh người tài (địa linh nhân kiệt). Do đó những chuyến đi sứ bang giao, nhiều sứ thần Việt Nam ngợi ca phong thổ Trung Hoa như những vùng đất thiêng sản sinh nhiều nhân kiệt. Có điều lạ là, trong suốt tập thơ Bắc hành, không thấy Nguyễn Du bàn đến "tú khí" hay "linh khí" của những vùng đất ông đến, chỉ thấy trong đó núi non sông ngòi được nhìn như sài lang hổ báo tinh ma muốn ra oai với người:

\section{到處江山如諳趣，喜人蛇虎不施威。}

《下灘喜賦》(Nguyễn, 1813, tr. 10a)

Phiên âm:

Đáo xú giang sơn như thức thú, Hỷ nhân xà hổ bất thi uy.

(Há than hỷ phú) dám ra oai.

Dịch: Sông núi khắp nơi dường như hiểu ta, mừng cho mọi người vì cọp rắn không 西粤山川多險晋，行行從此向天涯。 崩崖怪石怒相向, 水鳥沙擒狎不飛。

《舟行即事》(Nguyễn, 1813, tr. 8a)

Phiên âm:

Tây Việt sơn xuyên đa hiểm hy, Hành hành tùng thử huoóng thiên nhai.

Băng nhai quái thạch nộ tương hướng, Thuỷ điểu sa cầm hiệp bất phi.

\section{(Chu hành tức sụ̂)}

Dịch: Sông núi Quảng Tây nhiều hiểm trở, cứ đi mãi như lên đến chân trời. Vách núi như lở, hình đá quái dị giận dữ nhìn nhau, cả loài chim sông chim bãi nhờn người chẳng chịu bay.

Cái cảm thức nhìn núi sông đất khách trước tiết trời mưa lũ dữ dằn như loài sói hổ rắn rồng của Nguyễn Du quả thật không sứ thần Việt Nam nào viết:

雨師涕泣馮夷怒，五指山前水暴注。

白波終日走蛇龍, 青山兩岸皆豹虎。

《不進行》(Nguyễn, 1813, tr. 13a) 
Phiên âm:

Vũ sư thế khấp Phùng Di nộ, Ngũ Chỉ sơn tiền thuỷ bạo chú.

Bạch ba chung nhật tẩu xà long, Thanh sơn lương ngạn giai sài hổ. (Bất tiến hành)

Dịch: Quân mưa khóc lóc, Phùng Di (hà bá, sóng nước) như nổi giận, trước núi Ngũ Chỉ (năm ngón tay) thác nước trút mạnh. Suốt ngày sóng trắng đuổi chạy như rồng rắn, hai bờ núi xanh đều như sói cọp.

\section{CẢM THỨC VỀ XÂM THỰC VĂN HOÁ DỊ TộC VÀ SỰ LẶNG IM KỲ DI!}

Toàn tập Bắc hành tạp luc, ngoài cảnh sắc núi non sông ngòi mưa lũ được nhìn dưới góc nhìn kỳ lạ toàn là rắn rồng hổ báo yêu ma, ta còn thấy Nguyễn Du hoàn toàn không có tiếng nói đối thoại nào với nhân sĩ Thanh triều - một sự im lặng kỳ dị. Với tư cách là một đại bồi thần, chánh sứ sứ đoàn Việt Nam sao lại không có sự giao lưu đó như anh trai ông Nguyễn Đề thời Tây Sơn, hoặc như Trịnh Hoài Đức, Lê Quang Định, Ngô Nhơn Tịnh đầu triều Nguyễn, hoặc như Trương Hảo Hiệp, Bùi Tự, Nguyễn Tư Giản... sau này.

Cảm thức nào đã chi phối điều đó nếu không phải là sự nhận thức về văn hoá dị vực?

Cả tập thơ chỉ thấy Nguyễn Du tâm sự cùng những người đã khuất, những nhân vật lịch sử nổi tiếng Trung Hoa, mà trong đó, tài tử văn nhân chiếm đa số. Những suy nghĩ của Nguyễn Du về cuộc đời họ cũng nhiều khác lạ, mang tính phản tư, đối thoại. Trong cảm thức của Nguyễn Du phải chăng chỉ có họ - những con người đại diện cho văn hoá truyền thống Trung Hoa, chứ không phải là những con em Thanh triều của một thời đại mới - mới đáng để ông bàn luận? Phải chăng dưới sự cai trị của Thanh triều trong tâm tư Nguyễn Du là ngoại tộc là kẻ xâm chiếm đất nước Trung Hoa, là văn hoá dị vực - nên ông nín miệng không thèm đối thoại trực tiếp, mà mượn người xưa để bàn luận về văn hoá đương thời?

Đối thoại với Khuất Nguyên, ông cho rằng:

楚國冤魂葬此中，煙波一望渺何窮。

直交憲令行天下, 何有離騷繼國風。

千古誰人憐獨醒, 四方何處托孤忠。

近時每好為奇服, 所指椒蘭竟不同。

《湘潭虫三間大夫・其二》

(Nguyễn, 1813, tr. 15a)

Phiên âm:

Sở quốc oan hồn táng thử trung, Yên ba nhất vọng diểu hà cùng. 
Trục giao hiến lệnh hành thiên hạ, Hà hũu Ly tao kế Quốc phong.

Thiên cổ thuỳ nhân liên độc tỉnh, Tứ phwơng hà xú thác cô trung?

Cận thì mỗi hiếu vi kỳ phục, Sở bội tiêu lan cánh bất đồng

(Tương Đàm điếu Tam lu Đại phu, kỳ nhị)

Dịch: Hồn oan người nước Sở táng ở trong sông này, chỉ trông thấy khói sóng mênh mông chẳng dứt. Nếu hiến lệnh của ông được thi hành trong thiên hạ, thì Ly tao làm gì kế được thơ Quốc phong. Ngàn xưa nay có ai thương người độc tỉnh, khắp bốn phương đâu chỗ nào để ông gửi tấm lòng trung. Gần đây người ta thường thích mặc trang phục lạ, họ đeo hoa tiêu hoa lan mà sao chẳng giống ngày xưa!

Nguyễn Du đưa ra vấn đề về văn hoá Trung Hoa đã đổi thay. Chẳng còn ai nhớ Khuất Nguyên (tức nhớ đến chuyện mất nước), tấm lòng cô trung của ông cũng chẳng còn chỗ để nương dựa (nhà Thanh cai trị toàn cõi nước). Gần đây người ta thích trang phục lạ (trang phục của một dân tộc mới), họ cũng bắt chước đeo hoa lan hoa tiêu (giả đức, văn hoá khác lạ) mà thật sự khác ngày xưa, khác với ông lắm.

Xem đua thuyền rước hồn trong ngày mồng năm tháng năm, Nguyễn Du cho rằng hồn người yêu nước Khuất Nguyên không thể về nhân gian, bởi ở đó chỉ toàn rắn rết, không nơi nương tựa:

懷王歸葬張儀死, 楚國詞人記佩蘭。
天古招魂終不返, 滿江爭競太無端。
煙波泪少渺空悲怨, 羅鼓年年自笑歡。
魂若歸來也無托, 龍蛇鬼蜮遍人間。

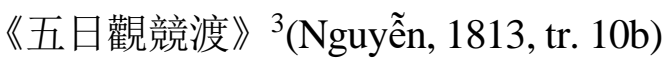

Phiên âm:

Hoài Vưong quy táng Truơng Nghi tủ, Sở quốc tù nhân ký bội lan.

Thiên cổ chiêu hồn chung bất phản, Mãn giang tranh cạnh thái vô đoan.

Yên ba diểu diểu không bi oán, La cổ niên niên tụ tiếu hoan.

Hồn nhược quy lai dã vô thác, Long xà quỷ vực biến nhân gian.

(Ngũ nhật quan cạnh độ)

Dịch: Sở Hoài Vương được đưa về chôn ở Sở, Trương Nghi cũng đã chết, ta thì nhớ người thơ nước Sở đeo hoa lan. Ngàn thuở gọi hồn nhưng không trở lại, đầy sông người ta đua thuyền rước hồn chẳng nghĩa chi. Khói sóng mịt mờ sông, chỉ có nỗi buồn

\footnotetext{
${ }^{3}$ Bản Mai Quốc Liên, Vũ Tuân Sán chép “ngũ nguyệt” (Mai \& Vũ, 2015), ở đây chúng tôi theo nguyên bản Hán văn, A.1494.
} 
oán, chiêng trống năm nào cũng gõ chỉ để tự mua vui. Hồn ông nếu quay về hẳn cũng không có chỗ nương tựa, bởi vì khắp nhân gian đều là loài rắn rồng quỷ quái.

Nguyễn Du cảm nhận về nhân gian Trung Hoa đương thời không phải là nơi hồn Khuất Nguyên có thể trở về. Cõi nhân gian đã trở thành một nơi hỗn độn mịt mờ tàn khốc. Vì thế Nguyễn Du còn bồi tiếp bài Phản chiêu hồn:

魂兮魂兮胡不歸, 東西南北無所依。

上天下地皆不可, 漂郢城中來何為。

城郭猶是人民非，塵埃滾滾汗人衣。

出者驅車入踞坐, 坐談立議皆臮豙。

不露爪牙與角毒，咬嚼人肉甘如飴。

君不見湖南數百州, 只有瘦㾑無充肥。

魂兮魂兮率此道, 三皇之後非其時。

早斂精神返太極, 慎勿再返令人虽。

後世人人皆上官, 大地處處皆泪羅。

魚龍不食豹虎食, 魂兮魂兮奈魂何。

《反招魂》(Nguyễn, 1813, tr. 15a)

Phiên âm:

Hồn hề hồn hề hồ bất quy? Đông tây nam bắc vô sở y!

Thương thiên ha địa giai bất khả, Yên Dĩnh thành trung lai hà vi?

Thành quách do thị nhân dân phi, Trần ai cổn cổn ố nhân y.

Xuất giả khu xa nhập cứ toạ, Toạ đàm lập nghi giai Cao Quỳ.

Bất lộ trảo nha dũ giác độc, Giảo tuớc nhân nhục cam nhu di.

Quân bất kiến: Hồ Nam sổ bách châu, Chỉ hưu sấu tích vô sung phì.

Hồn hề hồn hề suất thư đạo, Tam hoàng chi hậu phi kỳ thì.

Tảo liễm tinh thần phản thái cực, Thận vật tái phản linh nhân xuy.

Hậu thế nhân nhân giai Thuợng Quan, Đại địa xứ xư giai Mịch La.

Ngu long bất thực sài hổ thực, Hồn hề hồn hề nại hồn hà?!

\section{(Phản Chiêu hồn)}

Dịch: Hồn ơi hồn ơi sao chẳng về? đông tây nam bắc chẳng còn chỗ để nương tựa. Trên trời hay dưới đất cũng đều không thể, huống là đến thành Yên Dĩnh làm chi? Thành quách vẫn như cũ mà dân thì chẳng phải trước, bụi trần cuồn cuộn làm hoen áo 
người. Ra cửa thì ngồi xe, vào nhà thì chễm choẹ, đứng ngồi bàn luận tựa như ông Cao ông Quỳ. Họ chẳng để lộ nanh vuốt cùng nọc độc, mà ngấu nghiến thịt người như kẹo ngọt. Ông chẳng thấy: mấy trăm châu ở Hồ Nam, chỉ toàn những kẻ gầy gò không ai no đủ. Hồn ơi hồn ơi nếu theo con đường này, sau thời Tam hoàng không phải là thời của đạo nữa. Sớm thu tinh thần trở về thái cực, hãy thận trọng chớ trở lại đây để người ta cười mỉa. Người đời sau toàn là Thượng Quan, khắp nơi nơi đều là sông Mịch La. Cá rồng không đớp thì sói cọp cũng nuốt, hồn ơi hồn ơi biết làm sao!?

Ở đây những ẩn dụ được Nguyễn Du đẩy lên cùng cực để người đọc hình dung một cõi nhân gian lụi tàn, văn hoá đã bị đổi thay bởi một văn hoá khác. Một xã hội hoen ố bụi trần, thành quách vẫn như xưa, dân tình thay đổi. Con người giờ đã không còn văn hoá, đạo đức, chỉ toàn những kẻ thích khoe khoang (ngồi xe, chễm choẹ), giả dối (bàn luận như ông Cao ông Quỳ), nham hiểm (chẳng để lộ nanh vuốt cùng nọc độc), độc ác (ngấu nghiến thịt người)... Trong cái nhìn có phần nghiêm khắc về con người xã hội trên vùng đất thượng quốc của Nguyễn $\mathrm{Du}$, người ta không phải không thấy tính tự tổn dân tộc của ông. Nhưng trong cái nhìn và cách nghĩ đó của Nguyễn Du ta vẫn thấy có một sự điềm tĩnh cần thiết.

Khác với Lý Văn Phức sau này khi tranh biện về vấn đề Hoa-Di từng kiên quyết không chịu vào công quán, Nguyễn Du "mạnh dạn" tự cho mình là kẻ Nam Di, song hoàn toàn không có kiểu tự ti dân tộc, ngược lại cho thấy tiếng cười mỉa sâu kín về một dân tộc phương Nam có văn hoá chứ không phải bị xâm thực văn hoá như trên đất thượng quốc:

\section{浪花雙棹疾如飛, 看罷龍舟抵暮歸。 \\ 生面相逢無畏避, 瓠犀微露笑南夷。 \\ 《蒼梧竹枝歌・其五》 \\ (Nguyễn, 1813, tr. 11a)}

Phiên âm:

Lãng hoa song trạo tật nhu phi, Khán bãi long chu để mộ quy.

Sinh diện tuoong phùng vô uý ty, Hồ tê vi lộ tiếu Nam Di.

(Thuoong Ngô trúc chi ca, kỳ ngũ)

Dịch: Mái chèo rẽ sóng hoa lướt nhau như bay, xem thuyền rồng đến tối mới trở về. Lạ mặt nhìn nhau chẳng sợ né tránh, hé lộ răng đều như hát bí cười với người Nam Di.

Văn hoá để tóc dài truyền thống khác với văn hoá giát đầu tết tóc đuôi sam của Mãn Thanh, thế nên trong cái cách tự cho là "di” của Nguyễn Du, có cái thâm thuý của nhà nho truyền thống, mới đủ tư cách điếu hai bà phi của vua Thuấn:

‥ 一江新潦平三楚, 大半浮雲駐九疑。

窄窄小舟難過夏, 髧髧長髮自知夷。 


\section{平波日暮湘潭遠，杯酒憑欄中二妃。}

《蒼梧暮雨》(Nguyễn, 1813, tr. 10b)

Phiên âm:

Nhất giang tân lạo bình Tam Sở, Đại bán phù vân trú Cửu Nghi. Trách trách tiểu chu nan quá Hạ, Sam sam truoòng phát tụ tri Di. Bình ba nhật mộ Tương Đàm viến, Bôi tưu bằng lan điếu Nhị phi. (Thưong Ngô mộ vũ)

Dịch: Cả sông lũ về ngập bằng ba vùng đất Sở, mây đùn lấp nửa núi Cửu Nghi. Thuyền nhỏ hẹp khó qua vùng đất Hạ (Trung Hoa), tóc để dài búi to rõ biết mình là người Nam Di. Chiều tối sóng lặng còn cách Tương Đàm, nhưng ta cứ dựa lan can thuyền rót chén rượu điếu hai bà phi.

Tự cho mình là "Nam Di”, đồng thời Nguyễn Du gọi Trung Hoa là "thượng quốc", nhưng cách gọi ấy không tỏ ra chút rụt rè e ngại trên bình diện văn hoá. Người quân tử dầu ở trong hoàn cảnh nào vẫn có thể giữ đạo người quân tử. Khổng Tử từng than phiền về một tình trạng Trung Hoa không có vương đạo dưới thời nhà Chu đang dần mất ngôi thiên tử, được ghi lại trong sách Luận ngũu: “夷狄之有君不如諸夏之亡也” 《論語》 Di địch chi hũu quân bất nhu chu Hạ chi vô dã = Người di địch mà còn có vua, chăng giống nhu ở đất Hoa Hạ lại không có vua. Vì thế chiến tranh loạn lạc trên bất kỳ một vùng đất nào cũng là một sự rối loạn về thể chế kỷ cương, một sự rối loạn văn hoá. Cảm thức ấy được tìm thấy trong thơ Nguyễn Du khi ông bàn về Triệu Đà - một lão già Man Di trong thế đối lập với Hoa Hạ Tần Hán:

暴楚強秦相繼誅, 雍容揖遜霸南陬。

自娛儘可稱皇帝, 樂善還能屈豎儒。

百尺高臺傾嶺表，千年古墓沒番禺。

可憐世代相更迭, 不及蠻夷一老夫。

《趙武帝故境》(Nguyễn, 1813, tr. 12b)

Phiên âm:

Bạo Sở cương Tần tuơng kế tru, Ung dung ấp tốn bá Nam tưu. Tụ ngu tẫn khả xung hoàng đế, Lạc thiện hoàn năng khuất thụ nho.

Bách xích cao đài khuynh Lĩnh Biểu, Thiên niên cổ mộ một Phiên Ngu.

Khả liên thế đại tương canh điệt, Bất cập Man Di nhất lão phu. 
Dịch: Sở, Tần dù mạnh bạo vẫn nối nhau bị diệt, riêng ông ung dung nhún nhường xưng bá ở phía nam. Tự vui vì thoả sức xưng hoàng đế, vui điều lành nên vẫn có thể chịu khuất một kẻ nhà nho hèn. Đài cao trăm thước khuynh loát cả vùng Lĩnh Biểu, ngàn năm ngôi mộ xưa cùng mất ở chốn trời Phiên. Thương thay các đời (vua phía bắc) nối nhau thay đổi, chẳng bằng một lão già Man Di.

Đối sánh giữa Man Di với Hoa Hạ, giữa người Hán với người Mãn, trong cảm thức của Nguyễn Du cho thấy một sự diệt vong suy tàn của nền văn hoá nho gia truyền thống với nền văn hoá ngoại xâm:

$$
\begin{aligned}
& \text { 中原大勢已頽唐, 竭力孤城控一方。 } \\
& \text { 終日死中心不動, 千秋地下髮猶長。 } \\
& \text { 殘明廟社多秋草, 全越山河盡夕陽。 } \\
& \text { 共道中華尚節義, 如何香火太凄涼。 }
\end{aligned}
$$

《桂林篗閣部》(Nguyễn, 1813, tr. 13b)

Phiên âm:

$$
\begin{aligned}
& \text { Trung Nguyên đại thế dĩ đồi đương, Kiệt lục cô thành khống } \\
& \text { nhất phuoong. }
\end{aligned}
$$

Chung nhật tử trung tâm bất động, Thiên thu địa hạ phát do truòng.

Tàn Minh miếu xã đa thu thảo, Toàn Việt sơn hà tận tịch duơng. Cộng đạo Trung Hoa thuợng tiết nghĩa, Nhu hà huoong hoả thái the luong?

\section{(Quế Câm Cù các bộ)}

Dịch: Thế lớn Trung Nguyên đã lụi tàn, một mình dốc sức chống chọi một phương trong toà thành trơ trọi. Suốt ngày ở trong cái chết lòng vẫn không nao núng, ngàn thu dưới đất tóc vẫn để dài. Tông miếu nhà Minh tàn tạ trong cỏ thu, cả cõi đất Quảng Tây Quảng Đông chìm trong bóng xế. Ai cũng nói Trung Hoa chuộng điều tiết nghĩa, mà sao hương khói (cho người nghĩa dũng) hiu quạnh thế này?

Tuy nói chuyện Cù Thức Trĩ, nhưng thực ra là để đánh tiếng với văn hoá thời ấy. Văn hoá đạo đức nho gia dường như không còn thấy ở mảnh đất đã sinh ra nó. Phía trên Nguyễn Du cũng từng nói: "Cộng đạo Trung Hoa lộ thản bình", thì ở đây lại nói: "Cộng đạo Trung Hoa thương tiết nghĩa" (Ai cũng nói Trung Hoa chuộng điều tiết nghĩa), thế mà sao ngày nay không thấy hương khói cho những bậc nghĩa dũng? Câu hỏi đau đớn nảy ra từ một tấm lòng băn khoăn về văn hoá truyền thống (văn hoá Hán) của thượng quốc khiến người đời sau phải suy nghĩ giật mình. Điều đó cho thấy sự im lặng của Nguyễn Du với nhân sĩ Thanh triều, và cũng có thể lý giải cho việc thiếu vắng những bài thơ xướng thù cùng nhau. Thâm ý Nguyễn Du ít ai hiểu được, chỉ có những người nằm 
dưới mộ sâu, những đỉnh cao văn hoá mới có thể hiểu, mới có thể cảm thông. Vì thế trong thơ, Nguyễn Du chỉ bày tỏ tâm tình của mình với người xưa.

Với Giả Nghị ông thấy mình chẳng trái:

湘潭迟尺相鄰近，千古相逢兩不違。

《長沙賈太傅》(Nguyễn, 1813, tr. 16a)

Phiên âm:

Tương Đàm chỉ xích tương lân cận, Thiên cổ tương phùng lương bất vi.

\section{(Trường Sa Giả Thái phó)} thấy hợp.

Dịch: Tương Đàm gần gũi trong tấc gang, dẫu cách ngàn năm mà gặp nhau cũng

Với Đỗ Phủ, ông thấy mình đồng cảm, chỉ có ông mới hiểu tiếng thơ của Đỗ Phủ: 異代相憐空灑淚《来陽杜少陵墓·其一》

Phiên âm:

Dị đại tương liên không sái lệ (Lỗi Dương Đỗ Thiếu Lăng mộ, kỳ nhất)

Dịch: Tôi và ông tuy khác thời đại mà thương nhau đành rỏ lệ suông.

Với Văn Thiên Tường ông tiếc cho một sự xâm thực của văn hoá ngoại tộc:

山河風景尚依然，丞相孤忠萬古傳。

一渡淮河非故宇，重來江左更何年?

哀衷觸處鳴金石，怨血歸時化杜鵑。

南北只今無異俗, 夕陽無限往來船。

《渡淮河有感文丞將》(Nguyễn, 1813, tr. 19a)

Phiên âm:

Sơn hà phong cảnh thượng y nhiên, Thùa tướng cô trung vạn cổ truyền.

Nhất độ Hoài Hà phi cố vũ. Trùng lai Giang Tả cánh hà niên?

Ai trung xúc xú minh kim thạch, Oán huyết quy thì hoá đỗ quyên. 
Nam bắc chỉ kim vô dị tục, Tịch dương vô hạn vãng lai thuyền.

(Độ Hoài Hà hũu cảm Văn Thù̀a tướng)

Dịch: Phong cảnh núi sông vẫn như cũ, tấm lòng cô trung của Thừa tướng còn truyền mãi muôn đời. Vượt qua sông Hoài không còn là cõi đất xưa [Hán] nữa, biết năm nào mới lấy được lại miền Giang Tả? Lòng chân thành ai oán chạm vào đâu cũng vang tiếng đá vàng, máu oán hờn khi mất đi hoá thành tiếng đỗ quyên. Đến nay phong tục nam bắc không còn khác nhau, dưới bóng chiều vô hạn thuyền lại qua.

Phong tục bắc nam (Tống-Kim) dưới thời Văn Thiên Tường không còn khác nhau nữa, và bây giờ cũng thế. Một sự cảm nhận về văn hoá bị pha trộn trong đời sống và tâm thức nhân dân trong một nước lớn dưới sự cai trị của ngoại xâm.

Những bài thơ khác viết về Quản Trọng, Kê Khang cũng đều một ý như trên. Với Quản Trọng:

喜值聖朝公覆壽, 往來臺下雜華夷。

《管仲三歸臺》 (Nguyễn, 1813, tr. 30a)

Phiên âm:

Hỷ trị thánh triều công phúc đảo, Vãng lai đài hạ tạp Hoa Di.

(Quản Trọng tam quy đài)

Dịch: Mừng gặp thánh triều, công ông chở che cả thiên hạ, nên dưới đài [tam quy] người Hoa xen người Di lại qua.

Hai câu thơ mỉa mai sâu sắc chua cay. Câu trên như khen, câu dưới ngầm chê. Ý tứ thâm thuý này chỉ có ở thơ Nguyễn Du. Quản Trọng từng được Khổng Tử chê, cũng từng được Khổng Tử khen trong tác phẩm Luận ngưu, rằng: "nếu không nhờ Quản Trọng thì ta với người dân phải gióc tóc, mặc áo chéo vạt trái như kiểu mọi rợ rồi.” Nhưng những cố gắng đó của Quản Trọng, Trung nguyên vẫn không thể tránh được một cuộc hỗn nhập văn hoá từ những cuộc ngoại xâm của Nguyên Mông và Mãn Thanh về sau.

Viết về Kê Khang, Nguyễn Du nhận thấy trong tiếng đàn văn hoá đã lẫn điệu ngoại vực. Sự thay đổi về lễ nhạc chính là sự thay đổi thể chế văn hoá rất ghê gớm trong truyền thống nho gia phương Đông:

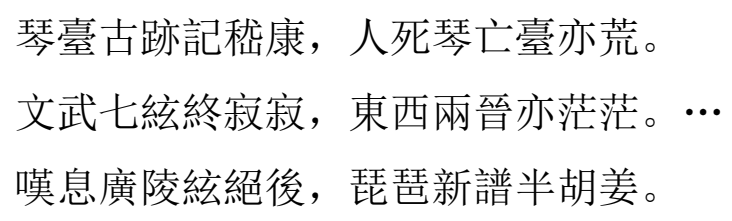

《嵇康琴臺》(Nguyễn, 1813, tr. 30a) 
Phiên âm:

Cầm đài cổ tích ký Kê Khang, Nhân tử cầm vong đài diệc hoang.

Văn võ thất huyền chung tịch tịch, Đông tây lương Tấn diệc mang mang....

Thán tưc Quảng lăng huyền tuyệt hậu, Tỳ bà tân phổ bán Hồ Khuơng. (Kê Khang cầm đài)

Dịch: Đến thăm dấu xưa nơi Kê Khang ngồi gảy đàn, người đã mất rồi đài cũng hoang vu. Bảy dây văn võ rốt cuộc vắng lặng, Đông Tấn, Tây Tấn cũng trở thành mịt mù... Than thở cho tiếng đàn Quảng lăng từ sau khi dứt khúc, khúc điệu tỳ bà một nửa pha điệu người Hồ Khương.

Bên cạnh đó, Nguyễn Du lên tiếng phê phán những kẻ gian xảo, phê phán những kẻ đạo đức giả (Tần Cối, Vương thị - vợ Tần Cối, Tào Tháo...) một cách gay gắt, mỉa mai. Điều đó cho thấy một xã hội loạn lạc, bất an:

一生心跡同夫婿，千古形骸辱女兒。

《王氏像・其一》(Nguyễn, 1813, tr. 23b)

Phiên âm:

Nhất sinh tâm tích đồng phu tế, Thiên cổ hình hài nhục nũu nhi.

(Vương thị tượng, kỳ nhất)

Dịch: Tâm tích một đời cũng giống chồng ả, hình hài kia ngàn thuở chỉ để nhục phận nữ nhi.

莫道女兒無力量, 也曾撼破岳家軍。

《王氏像・其二》(Nguyễn, 1813, tr. 23b)

Phiên âm:

Mạc đạo nũ nhi vô lực lượng, Dã tằng hám phá Nhạc gia quân.

(Vuơng thị tượng, kỳ nhị)

Dịch: Chớ bảo nữ nhi không có sức lực, ả đã từng phá tan cả quân của Nhạc Phi.

Đối lập với những kẻ không giữ phụ đạo như Vương thị, Nguyễn Du lên tiếng ca ngợi những phụ nữ trinh liệt tiết hạnh như ba người nhà họ Lưu, Trương, Quách (Tam liệt), hay bênh vực Dương Quý Phi, đả kích những nam tử hán nhu nhược giả dối, đớn hèn trong xã hội:

蔡女生雛卓女奔, 落花飛絮不勝言。 
千秋碑碣顯三烈，萬古綱常屬一門。

地下相看無愧色，江邊何處吊貞魂。

清時多少鬚如戟, 說孝談忠各自尊。

《三烈廟》(Nguyễn, 1813, tr. 13a)

Phiên âm:

Sái nũ sinh sồ Trác nũ bôn, Lạc hoa phi như bất thăng ngôn.

Thiên thu bi kiệt hiển tam liệt, Vạn cổ cuoong thuờng thuộc nhất môn.

Địa ha tưong khan vô quý sắc, Giang biên hà xú điếu trinh hồn.

Thanh thì đa thiểu tu nhu kích, Thuyết hiếu đàm trung các tự tôn.

(Tam liệt miếu)

Dịch: Ả Sái (Sái/ Thái Văn Cơ) sinh con, họ Trác (Trác Văn Quân) bỏ theo trai, như hoa rơi tơ bay chẳng biết nói thế nào. Ngàn năm bia đá còn ghi chuyện ba người liệt nữ, vạn thuở mối cương thường thuộc về một nhà. Dưới suối vàng nhìn nhau chẳng thẹn lòng, bên sông chừ có nơi nào để điếu hồn người trinh tiết? Lúc thanh bình biết bao nhiêu kẻ vênh râu như giáo nhọn, nói hiếu nói trung ai cũng tự tôn mình.

Những nghĩa sĩ liệt nữ dường như ít còn trên đời, họ đã tập hợp ở một nơi vắng lặng - u giới. Vì thế Nguyễn Du im lặng đến kỳ dị khi không thù xướng thi ca cùng các nhân sĩ Thanh triều trên đường đi sứ mà chỉ đối thoại cùng người xưa, bày tỏ lòng mình với những u hồn trung trinh nghĩa liệt.

Trong bài Liêm Pha bi, Nguyễn Du nhắc lại tình hình rối loạn khi những kẻ vô sỉ xu thời, không xem các bậc hiền năng đời trước ra gì như một kiểu đổ vỡ văn hoá:

\section{清平時節無戰爭，一口雄談不數廉頗與李牧 \\ 《廉頗碑》(Nguyễn, 1813, tr. 25b)}

Phiên âm:

Thanh bình thời tiết vô chiến tranh, Nhất khẩu hùng đàm bất tri Liêm Pha dũ Lý Muc.

(Liêm Pha bi)

Dịch: Lúc thanh bình không có chiến tranh, ai cũng nói rất hùng dũng, chẳng còn biết có Liêm Pha với Lý Mục.

Nhiều bài thơ miêu tả cảnh đời sống nhân dân Trung Hoa dưới Thanh triều đói khổ, cơ cực (Thái Bình mại ca giả, Sở kiến hành), hay cảnh loạn lạc (Trở binh hành), hay 
cảnh quan lại đi tuần tra nhưng chỉ ghé thăm các thuyền hoa của kỹ nữ để thấy một xã hội nhiễu loạn điên đảo:

$$
\begin{gathered}
\text { 船尾燈籠四尺竿，船頭畫虎黑斑斑。 } \\
\text { 布旗上冩巡河字，只詰花船不詰姦。 } \\
\text { 《蒼梧竹枝歌・其十五》 } \\
\text { (Nguyễn, 1813, tr. 12a) }
\end{gathered}
$$

Phiên âm:

Thuyền vĩ đăng lung tư xích can, Thuyền đầu hoạ hổ hắc ban ban.

Bố kỳ thượng tả "tuần hà" tụ, Chỉ cật hoa thuyền bất cật gian.

(Thuoong Ngô trúc chi ca, kỳ thập ngũ)

Dịch: Đuôi thuyền treo đèn lồng, sào dài bốn thước, đầu thuyền vẽ cọp lấm tấm đen. Trên cờ đề chữ "tuần sông", sao chỉ thấy hỏi thuyền hoa mà chẳng xét kẻ gian?

Bên cạnh những phê phán, Nguyễn Du cũng mạnh dạn đứng về phía những người dân cơ cực, những nhân vật văn hoá lô̂i lạc, những nhà tư tưởng đạo đức trứ danh trên đất Trung Hoa như những đại diện cho một nền văn hoá huy hoàng trong quá khứ. Trong cảm thức của Nguyễn Du về một xã hội thượng quốc trước, trong và trên đường đi sứ có những chuyển biến rõ rệt. Viễn tượng tốt đẹp về một đất nước văn hoá văn minh của một nước lớn đã theo đường đi sứ nhoà hẳn trong tâm thức của một Việt nho, ngược lại tô đậm cảm thức mới về sự suy tàn văn hoá ngay trên mảnh đất đã sinh ra nó. Vượt sông Hoàng Hà trong mùa lũ, Nguyễn Du không quên người xưa trị thuỷ có công, nhưng cũng từ đó, ông băn khoăn về truyền thuyết năm trăm năm nước sông Hoàng Hà trong xanh và thánh chúa xuất hiện:

一氣茫茫混沌前, 其來無際去無邊。

天河巨派九千里, 聖主休期五百年。…

《黃河》(Nguyễn, 1813, tr. 20b)

Phiên âm:

Nhất khí mang mang hỗn độn tiền, Kỳ lai vô tế khư vô biên.

Thiên hà cự phái cửu thiên lý, Thánh chủ huu kỳ ngũ bách niên.

(Hoàng Hà)

Dịch: Một bầu khí nước mênh mông hỗn độn phía trước, chẳng biết từ đâu chảy đến và trôi về đâu. Nhánh sông lớn từ sông trời (Ngân) chảy dài chín ngàn dặm, Thánh chủ chờ dịp tốt đến năm trăm năm mới ra đời. 
Cũng cần nói thêm, "hưu kỳ 休期" vừa có nghĩa là "thời cơ tốt, giờ lành" (như 庥期) nhưng cũng có thể hiểu là "chớ mong gì, đừng mong gì”. Một sự chơi chữ "vô tình" hay "hữu ý" của Nguyễn Du để bình luận về nhà cầm quyền đương thời. Thánh chúa xuất hiện hẳn không phải là thời ấy. Cái cảm thức đó còn hé lộ trong bài thơ viết về mộ con Kỳ lân bị giết chết:

\section{… 吁嗟仁獸兮騏麟。 \\ 於世不見以為祥，見之不過同犬羊。 \\ 若道能為聖人出, 當世何不南遊翔。}

《騏麟墓》(Nguyễn, 1813, tr. 28b)

Phiên âm:

... Hu ta nhân thú hề kỳ lân.

U thế bất kiến dĩ vi tuờng, Kiến chi bất quá đồng khuyển duong.

Nhược đạo năng vi thánh nhân xuất, Đưong thế hà bất Nam du tuòng.

(Kỳ lân $m o \hat{)})$

Dịch: Than ôi kỳ lân là loài thú có đức nhân, ở đời khó thấy nên cho là điềm lành, khi thấy nó rồi thì chẳng khác gì con chó con dê. Nếu bảo rằng kỳ lân hiện là điềm thánh nhân ra đời, sao buổi ây ngươi chẳng bay sang cõi Nam?

Lân xuất hiện cũng là điềm thánh nhân ra đời. Thế mà con kỳ lân lại bị giết ngay trên mảnh đất ấy. Nếu tính thời gian con kỳ lân này xuất hiện ứng vào khoảng đầu thế kỷ 15, tức khi đó Lê Lợi khởi nghĩa. Vì thế, Nguyễn Du cho rằng ở nước Nam ta có thánh nhân xuất hiện, sao kỳ lân không đi về phương Nam, mà hiện ra ở xứ này để rồi bị giết hại? Tiếc cho kỳ lân xuất hiện không đúng thời không đúng chỗ: ở đó, những con người xa lạ với văn hoá truyền thống, dữ độc và hiểm ác đang tồn tại trên nhân gian.

\section{KẾT LUẬN}

Đọc lại thơ chữ Hán Nguyễn Du, chợt thấy còn nhiều vấn đề cần tiếp tục làm sáng tỏ. Thơ chữ Hán Nguyễn Du cũng độc đáo kỳ tuyệt như Truyện Kiều. Tập thơ Bắc hành tạp luc, dù có thể chưa hoàn chỉnh về văn bản, có thể khuyết thiếu những sáng tác mà đến nay ta chưa tìm thấy. Nhưng từ tư liệu hiện nay, rằng đây là một tác phẩm thơ đi sứ hiếm có trong văn học Hán Nôm Việt Nam là điều xác thực. Nói rằng hiếm có, bởi khi tiến hành khảo sát toàn bộ tập thơ Bắc hành tạp luc của Nguyễn Du, người viết thấy có ba điều kỳ: 1) góc nhìn kỳ dị (cảnh vật con người); 2) suy nghĩ kỳ dị (đối với văn hoá thượng quốc); 3) im lặng kỳ dị (không thấy có bài nào mang tính giao lưu xướng hoạ cùng các văn nhân Thanh triều?). Nhưng ở đó sự phản tư và đối thoại về các giá trị văn hoá lại nổi bật lên hơn bao giờ hêt giữa hai thế giới người sống và người chêt, giữa hai đất nước, giữa hai thực tại văn hoá bắc và nam trong cảm thức của một Việt nho trên đất khách. 
Phải chăng đó là một trong những yếu tính làm nên một Tố Như tử Nguyễn Du - đỉnh núi cao nhất trong hàng trăm ngọn núi ở Hồng Sơn của nước Nam?

\section{LỜI CẢM ƠN}

Nghiên cứu được tài trợ bởi Đại học Quốc gia Thành phố Hồ Chí Minh (ĐHQGHCM) trong khuôn khổ Đề tài mã số B2020-18b-02.

\section{TÀI LIỆU THAM KHẢO:}

Khoa Văn học và Ngôn ngữ. (2015). Đại thi hào dân tộc, Danh nhân văn hoá Nguyến $D u$. Đại học Quốc gia Thành phố Hồ Chí Minh.

Huỳnh, N. P., \& Đoàn, L. G. (2015). Đại thi hào dân tộc, Danh nhân văn hoá Nguyến $D u$. Đại học Quốc gia Thành phố Hồ Chí Minh.

Mai, Q. L., \& Vũ, T. S. (Dịch chú). (2015). Nguyễn Du - Toàn tập (Tập 2). NXB Văn học.

Nguyễn, T. G., \& Trương, C. (Chủ biên). (2001). Nguyễn Du, niên phổ và tác phẩm. NXB Văn hoá thông tin.

Nguyễn, D. (阮做). (1813). Bắc hành tạp lục (北行襍錄) (A.1494). Thư viện Viện Nghiên cứu Hán Nôm lưu trữ. 